\title{
The Real Estate Market and Financial Stability
}

\author{
My-Linh Thi Nguyen \\ Faculty of Finance and Banking, \\ University of Finance - Marketing (UFM), Vietnam. \\ E-mail: ntmylinh@ufm.edu.vn \\ Toan Ngoc Bui \\ Faculty of Finance and Banking, \\ Industrial University of Ho Chi Minh City (IUH), Vietnam. \\ Corresponding author: buingoctoan@iuh.edu.vn
}

(Received March 16, 2020; Accepted May 19, 2020)

\begin{abstract}
This paper investigates the relationship between the real estate market (REM) and financial stability in Vietnam. Financial stability is measured using stock market volatility. The research is performed in Vietnam, a developing country whose stock and real estate markets are considered to be nascent, so the data series is very short. To solve this problem, the autoregressive distributed lag (ARDL) approach, which generates more valid results than its counterparts, is adopted. Furthermore, the ARDL approach is appropriate for a model with non-stationary data series and especially allows the analysis of the impact between data series in the short run and the long run. The results reveal the positive relationship between the real estate market and stock market volatility. However, this correlation only exists in the short run, which is a difference between Vietnam and developed countries. The paper also obtains an unprecedented finding confirming that the global financial crisis exerted a negative impact on the REM in Vietnam in the short run and the long run.
\end{abstract}

Keywords- Financial development, Global financial crisis, Real estate market, Stock market volatility, Vietnam.

\section{Introduction}

Financial stability reflects the stability of the financial system in performing its basic functions. Financial stability is frequently associated closely with the real estate market. Therefore, investors always pay more attention to the nexus between financial stability (particularly from the perspective of the stock market) and the REM, because these markets are always attractive to them (Liu and $\mathrm{Su}, 2010$ ). The stock market is an appealing investment channel with relatively high liquidity, low trading costs, and especially more explicit trading information than other channels (Lin and Lin, 2011; Bui, 2019a, 2020). Meanwhile, real estate market is a counterpart with high asset value, low liquidity, and high trading costs (Lin and Fuerst, 2014; Bui, 2019b). Consequently, they are two appealing investment channels that can share common risks and allow portfolio diversification (Lin and Fuerst, 2014; Nguyen and Bui, 2019).

In fact, financial stability is closely correlated to the REM. On the one hand, the REM exerts a significant influence on collateral values as well as the ability to approach capital using mortgagebacked securities (Kiyotaki and Moore, 1997; Quigley, 2001; Raza et al., 2018). Thus, it plays a crucial role in stabilising the financial system. On the other hand, financial stability strongly influences the amount of capital entering the REM (Liu et al., 2020). Hence, it can be concluded that there is a potential bidirectional association between the REM and financial stability. The majority of empirical studies have measured financial stability from the angle of the financial 
International Journal of Mathematical, Engineering and Management Sciences

Vol. 5, No. 6, 1270-1283, 2020

https://doi.org/10.33889/IJMEMS.2020.5.6.094

system (e.g. Liu et al., 2020) or banking system (e.g. Zhang et al., 2016). Very few numbers of studies have adopted the stock market as a measure. Meanwhile, the stock market is a sensitive one that usually experiences more fluctuations than other elements of the financial system. Therefore, the interaction between the real estate market and financial stability (through the stock market) is an interesting research topic for more investigation.

In Vietnam, the stock and real estate markets are regarded to be quite nascent but they have experienced really impressive developments, especially in terms of market size. Indeed, stock market capitalization was reported to quadruple in the last ten years, from $12.47 \%$ in 2008 to $54.10 \%$ in 2018 (Figure 1). More than that, the Vietnam stock market has attracted a large number of foreign and domestic investors (Bui, 2020).

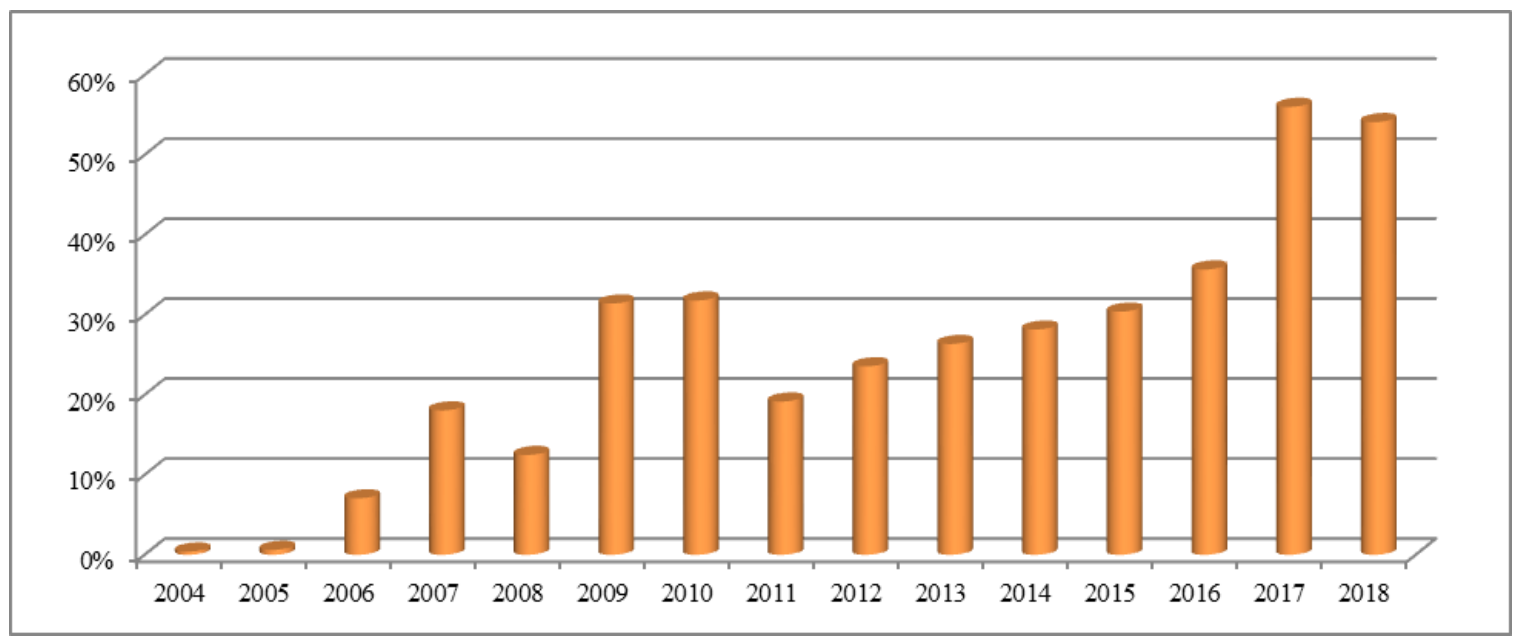

Figure 1. Stock market capitalization to GDP (\%)

Vietnam's real estate market was officially operated on July $1^{\text {st }}, 2004$ after the 2003 Law on Land was issued. Despite being young, this market has become an attractive investment channel to many investors. Particularly, the real estate market was a major contributor to Vietnam's GDP. Indeed, the real estate business accounts for about 4\%-6\% of GDP, which significantly increased following the global financial crisis (Figure 2).

In this research, we analyse the nexus between the REM and financial stability (from the angle of the stock market) in Vietnam. This is regarded as a developing country whose stock and real estate markets are nascent and attract considerable attention from investors, so this study is expected to contribute to the current literature. The remainder of the paper consists of a literature review, the data and methodology, the results and a discussion, and eventually the conclusion. 


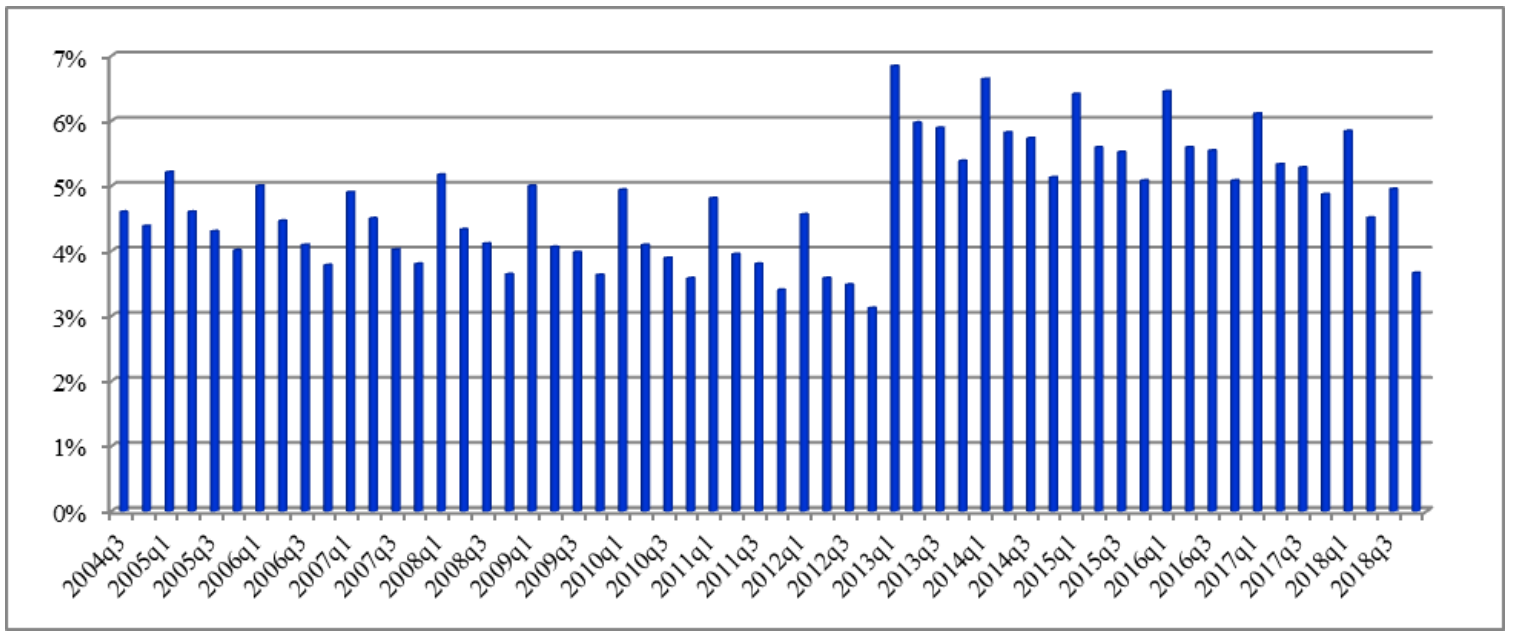

Figure 2. Real estate industry's contribution to GDP

\section{Literature Review}

Besides reflecting a healthy financial system, financial stability is an important indicator of financial development, which is often measured by the development of the banking sector and the stock market (Pradhan et al., 2014; Bui, 2020; Nguyen et al., 2020). As a result, financial stability is frequently measured using the stability of the banking sector and the equity market. However, some scholars have proposed non-performing loans of banking sectors to gauge financial stability (Zhang et al., 2016). In addition, a financial stress index which is formed by fluctuations in the banking sector, stock market, and foreign exchange market (Illing and Liu, 2006; Park and Mercado, 2014; Liu et al., 2020) has been suggested as a measure. Accordingly, a low financial stress index, which means fewer fluctuations in the financial system, corresponds to high financial stability and vice versa. In the scope of this paper, we mainly review the linkage between the REM and financial stability (from the perspective of the equity market).

The impact of the REM on financial stability can be explained using the credit effect. Particularly, the development of the real estate market corresponds to an increase in property values, so it is easier for investors to access financing through mortgage-backed securities to expand their portfolios in the stock market, thereby increasing the stock price (low financial stability). The causality between the REM and financial stability was noticeable during the global financial crisis in 2007. During this time, a recession in the real estate market was the antecedent of the instability and dramatic decline in the American stock market (Bahmani-Oskooee and Ghodsi, 2018) as well as the financial crisis (Zhang et al., 2016). More seriously, this crisis has spread globally (Moscone et al., 2014).

The impact of financial stability on the REM can be described through the wealth effect. Specifically, more fluctuations in the stock market cause a rise in stock prices (low financial stability) and the security value of portfolios, which then make investors rebalance their current portfolios with more invested assets, such as real estate (Markowitz, 1952; Kapopoulos and Siokis, 2005). They also tend to increase their consumption, housing demand, and investment in real estate (Kapopoulos and Siokis, 2005). Consequently, stock market volatility, in correspondence with the rise in stock prices, leads to an increase in real estate investment and 
International Journal of Mathematical, Engineering and Management Sciences

Vol. 5, No. 6, 1270-1283, 2020

https://doi.org/10.33889/IJMEMS.2020.5.6.094

eventually boosts the REM (Lean and Smyth, 2014). This is consistent with what has been confirmed by Ibrahim (2010), Ding et al. (2014), Lean and Smyth (2014). However, the excessive capital entering the REM could stimulate real estate bubbles, thereby increasing the risk of a crisis (Tsai et al., 2011). Admittedly, financial stability significantly influences the real estate market.

A potential two-way causality exists between REM and financial stability. Particularly, the combination of wealth and credit effects can produce a credit cycle effect (Petrova, 2010). This association has been investigated in a number of empirical studies. Specifically, Heaney and Sriananthakumar (2012) revealed the positive link between stock market volatility and the REM in Australia from the third quarter of 1986 to the same period of 2009, which was obviously observed during the global financial crisis. In their analysis, Zhang et al. (2016) confirmed that financial stability was closely associated with the amount of capital in China real estate market in the 2000-2009 period. Moreover, Shi et al. (2017) argued that the linkage between stock price volatility and the REM changes over time and across places. Recently, in another analysis in China between January 2005 and April 2018, Liu et al. (2020) reported the bidirectional correlation between financial stability and REM, but the impact of financial stability on the REM outweighed the impact in the reverse direction.

Generally, limited empirical research has investigated the linkage between the REM and financial stability which has mostly been observed from the angle of financial or banking systems. There has been a lack of analysis of financial stability via the stock market, although this is considered to be a sensitive market that experiences more frequent changes than other elements of the financial system.

\section{Data and Methodology}

\subsection{Data Collection}

Being officially launched on 28 July 2000, the Vietnam stock market started its operations on a small scale, which did not attract much participation from investors. It, however, started to perform efficiently in Vietnam no sooner than 2004. Further, the Vietnam property market was officially implemented on July $1^{\text {st }}, 2004$ after the 2003 Land Law came into force, so the authors can only collect the data afterward. In addition, due to the fact that data on the real estate market and economic growth are released quarterly only, we collect quarterly data for the period from Q3 2004 to Q4 2018.

Regarding stock market volatility, we obtain data from the State Securities Commission of Vietnam (SSC). Meanwhile, the data on the real estate market, economic growth, and consumer price index are gathered from the General Statistics Office of Vietnam (GSO).

\subsection{Methodology}

The autoregressive distributed lag (ARDL) approach suggested by Pesaran et al. (2001) is employed to examine the relationship between the REM and financial stability in Vietnam. This approach is superior to other analyses due to its appropriateness for short time series (Pahlavani et al., 2005), particularly non-stationary one (Tursoy and Faisal, 2016). Together with the estimation by the ARDL, the unit root test suggested by Dickey and Fuller (1979), and bound test suggested by Pesaran et al. (2001) are also adopted. Accordingly, the ARDL approach should only be used if the time series is non-stationary and the bond test shows the long-run cointegration among the data series. 
International Journal of Mathematical, Engineering and Management Sciences

Vol. 5, No. 6, 1270-1283, 2020

https://doi.org/10.33889/IJMEMS.2020.5.6.094

Following Liu et al. (2020), stock market volatility (SMV) is chosen as a proxy of financial stability. However, this analysis is conducted from the perspective of the equity market, not the entire financial system like that of Liu et al. (2020). Accordingly, it is anticipated to demonstrate financial stability clearly from the stock market's angle. High stock market volatility (SMV) indicates low financial stability and vice versa. This is also one of the World Bank's essential indicators of financial development. Regarding the real estate market, the measurement is performed through its growth index, which has previously been used by Lambertini et al. (2017), Nguyen et al. (2019). Additionally, economic growth (GDP) and consumer price index (CPI), which were also used by Ibrahim (2010) and Choi and Park (2017), as well as the global financial crisis, are adopted as control variables. Together with domestic macroeconomic variables, the global financial crisis actually is crucial in the correlation between the REM and financial stability. This was previously mentioned by Heaney and Sriananthakumar (2012), Huang et al. (2015). Hence, we decide to adopt this factor in this analysis, which is a novelty of this research. The global financial crisis (GFC) is believed to be essential as a control variable in the model and as an indicator of a healthy global financial system. Specifically, the global financial crisis is measured using a dummy variable that is equal to 1 during the global financial crisis (from Q3 2007 to Q1 2013) and 0 for the other periods, following Hui and Chan (2014) and Cayon et al. (2018).

To consider the correlation between the REM and financial stability in Vietnam, we propose two research models in the following equations:

Model 1: The impact of the REM on financial stability:

$\mathrm{SMV}=\mathrm{f}(\mathrm{REM}, \mathrm{GDP}, \mathrm{CPI}, \mathrm{GFC})$

Model 2: The impact of financial stability on the REM:

$\mathrm{REM}=\mathrm{f}(\mathrm{SMV}, \mathrm{GDP}, \mathrm{CPI}, \mathrm{GFC})$

The models analysing the correlation between REM and financial stability in Vietnam are presented in Figure 3. Accordingly, Model 1 represents the impact of the REM on financial stability while Model 2 shows the impact of financial stability on the REM.

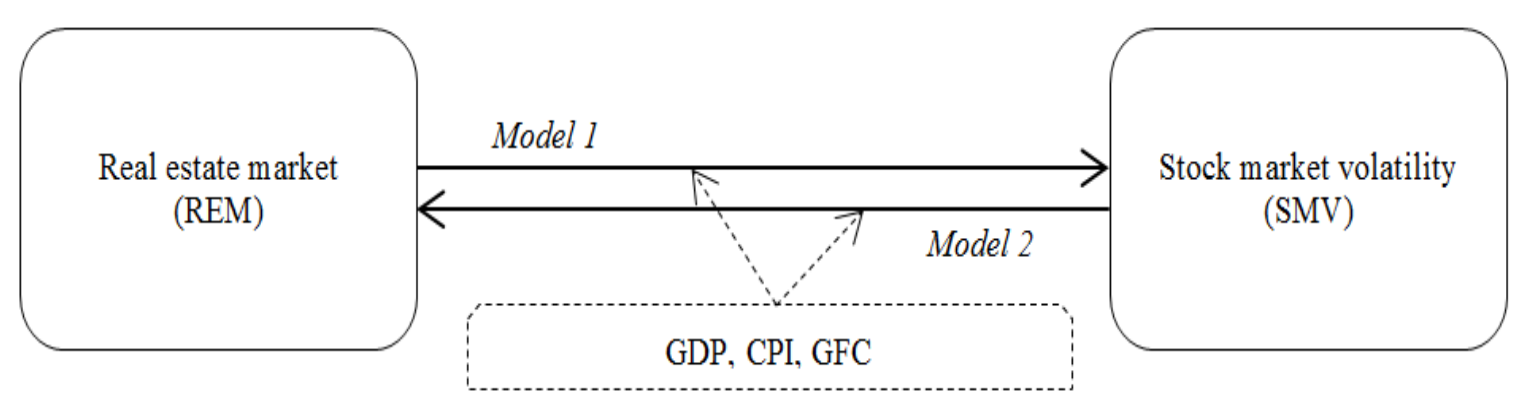

Figure 3. Proposed research models 
International Journal of Mathematical, Engineering and Management Sciences

Vol. 5, No. 6, 1270-1283, 2020

https://doi.org/10.33889/IJMEMS.2020.5.6.094

The variables in the models are presented in Table 1 as follows:

Table 1. Summary of the variables

\begin{tabular}{|l|l|l|}
\hline VARIABLE & CODE & MEASURE \\
\hline Variable of financial stability & SMV & Quarterly standard deviation of stock index growth. \\
\hline Stock market volatility & SMV \\
\hline Variable of the REM & REM & Quarterly growth of real estate business. \\
\hline REM & GDP & Quarterly growth of the gross domestic product. \\
\hline Control variables & CPI & Quarterly growth of the consumer price index. \\
\hline Economic growth & GFC & $\begin{array}{l}\text { GFC }=1 \text { during the global financial crisis (between Q3 2007 and Q1 2013); GFC } \\
=0 \text { during the non-crisis time (the remaining periods). }\end{array}$ \\
\hline Consumer price index &
\end{tabular}

\section{Results and Discussion}

\subsection{Descriptive Data}

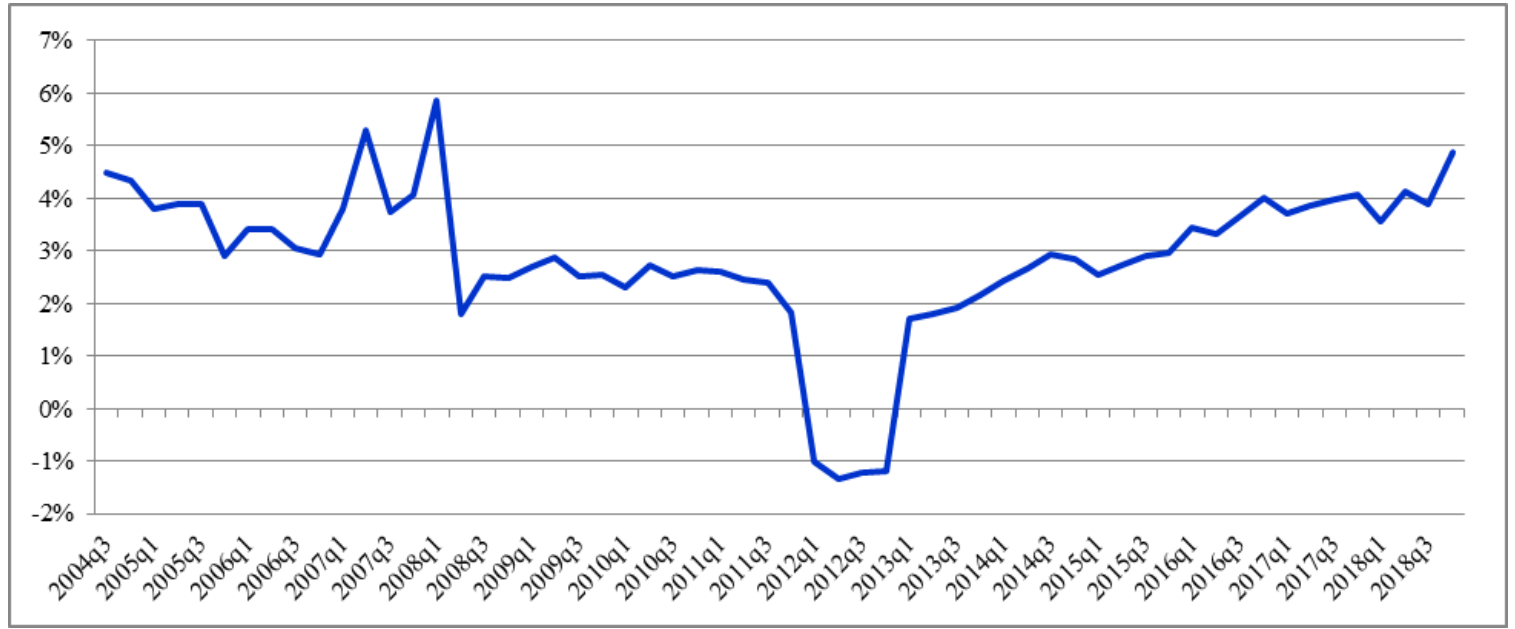

Figure 4. Developments of Vietnam's REM

The growth of Vietnam's REM reached a peak in Q1 2008 (with a growth of 5.87\% over the corresponding period last year) and fell to a trough in the second quarter of 2012 (with a growth of $-1.34 \%$ over the corresponding period last year) (Figure 4). In fact, Vietnam's real estate market has experienced continual changes over time, reaching a peak between 2007 and early 2008, when the capital entering the real estate market rose. However, it started to fall dramatically in the second quarter of 2008, receiving a considerable impact from the global financial crisis. This decline remained until 2012, when the highly increased inventory made it difficult to access the capital from the economy. Since the end of 2013, the real estate market has gradually recovered and climbed. 


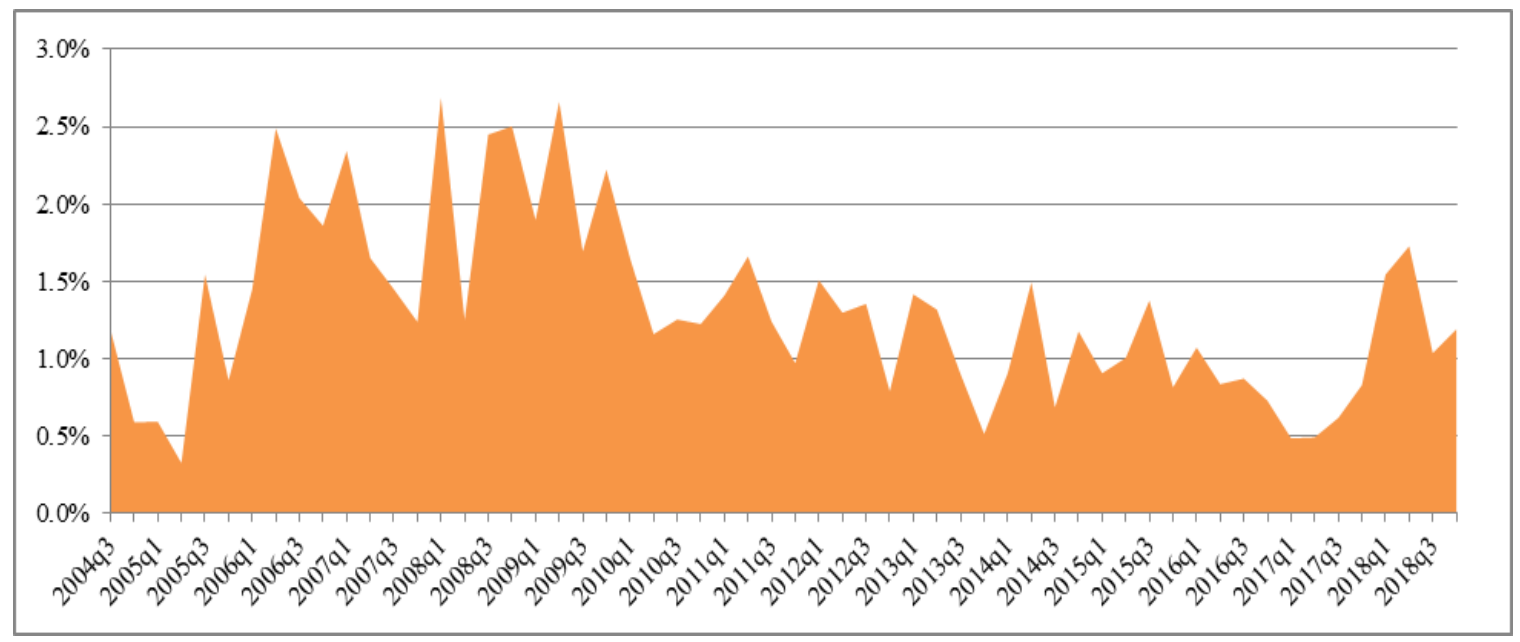

Figure 5. Stock market volatility in Vietnam

Figure 5 reveals the reality of financial stability through the stock market's angle in Vietnam. As can be seen, the stock market fluctuated regularly during the study period, indicating its instability. Indeed, it fluctuated most in the global financial crisis, particularly from late 2007 to 2009. Moreover, this fluctuation reached a peak when the stock market experienced a dramatic growth between 2006 and 2007, especially marked by the event of becoming an official member of the World Trade Organization (WTO). The market has gradually stabilised and recovered in recent years.

\subsection{Unit Root Test}

Next, we examine the stationarity of the data series by employing the augmented Dickey-Fuller test (Dickey and Fuller, 1979). Hypothesis $\mathrm{H}_{0}$ : The time series is non-stationary.

Table 2. Unit root test results

\begin{tabular}{|l|c|c|}
\hline \multirow{2}{*}{ VARIABLE } & AT LEVEL & AT $\Delta$ \\
\cline { 2 - 3 } & I(0) & I(1) \\
\hline SMV & $0.001^{* * *}$ & $0.000^{* * *}$ \\
\hline REM & 0.117 & $0.000^{* * *}$ \\
\hline GDP & $0.045^{* *}$ & $0.000^{* * *}$ \\
\hline CPI & 0.461 & $0.001^{* * *}$ \\
\hline GFC & 0.562 & $0.000^{* * *}$ \\
\hline
\end{tabular}

Note: ${ }^{* *}$ and ${ }^{* * *}$ indicate significance at the $5 \%$ and the $1 \%$ level, respectively.

It can be observed from Table 2 that stock market volatility (SMV) and economic growth (GDP) are stationary at the root time series $\mathrm{I}(0)$ and significant at the $1 \%$ and $5 \%$ level, respectively. The other variables become stationary after taking the first difference I(1) at the $1 \%$ significant level. It can be deduced that the series is non-stationary. Alternatively, the research models are correlated with the ARDL approach. 
International Journal of Mathematical, Engineering and Management Sciences

Vol. 5, No. 6, 1270-1283, 2020

https://doi.org/10.33889/IJMEMS.2020.5.6.094

\subsection{Cointegration Test}

The Bayesian information criterion (BIC) is employed to determine the lag of variables. Concurrently, the ARDL bound test suggested by Pesaran et al. (2001) is adopted to examine the cointegration among the time series. Hypothesis $\mathrm{H}_{0}$ : The cointegration does not really exist among the time series.

Table 3. Cointegration test results

\begin{tabular}{|c|c|c|}
\hline \multicolumn{3}{|c|}{ Model 1: The impact of the REM on financial stability. } \\
\hline \multirow{2}{*}{ p-value } & $\mathrm{I}(0)$ & $0.000^{* * * *}$ \\
\hline & $\mathrm{I}(1)$ & $0.001^{* * *}$ \\
\hline \multicolumn{3}{|c|}{ Model 2: The impact of financial stability on the REM. } \\
\hline \multirow{2}{*}{ p-value } & $\mathrm{I}(0)$ & $0.004^{* * *}$ \\
\hline & $\mathrm{I}(1)$ & $0.024^{* *}$ \\
\hline
\end{tabular}

Note: ${ }^{* *}$ and ${ }^{* * *}$ indicate significance at the $5 \%$ and the $1 \%$ level, respectively.

Table 3 reveals that, in the two models, the values of $F$ are beyond the upper bound I(1) and significant at the $1 \%$ and the $5 \%$ level, respectively. It can be concluded that the cointegration really exists among the time series. Alternatively, the ARDL approach functions successfully in considering the relationship between the REM and financial stability in the long run and short run.

\subsection{Results of Coefficient Estimation}

The results obtained from using the ARDL estimator to test the relationship between the REM and financial stability in Vietnam are as follows:

Table 4. Coefficient estimation results (Model 1)

\begin{tabular}{|c|c|c|}
\hline \multirow{2}{*}{ VARIABLE } & \multicolumn{2}{|c|}{ MODEL 1} \\
\hline & Coef. & $\mathbf{P}>|\mathbf{t}|$ \\
\hline \multicolumn{3}{|l|}{ Long-run results } \\
\hline REM & 0.082 & 0.342 \\
\hline GDP & 0.086 & 0.283 \\
\hline CPI & $0.098^{* * *}$ & 0.001 \\
\hline GFC & -0.002 & 0.492 \\
\hline \multicolumn{3}{|l|}{ Short-run results } \\
\hline$\triangle \mathrm{REM}$ & $0.253^{* * *}$ & 0.001 \\
\hline$\triangle \mathrm{GDP}$ & 0.059 & 0.282 \\
\hline$\triangle \mathrm{CPI}$ & $0.064^{* *}$ & 0.041 \\
\hline$\triangle \mathrm{CPI}(-1)$ & $-0.090^{* * *}$ & 0.004 \\
\hline$\triangle \mathrm{GFC}$ & -0.002 & 0.482 \\
\hline $\operatorname{ECM}(-1)$ & $-0.687^{* * *}$ & 0.000 \\
\hline Constant & -0.001 & 0.784 \\
\hline R-squared & \multicolumn{2}{|c|}{$56.61 \%$} \\
\hline Significance level & \multicolumn{2}{|c|}{$0.000^{* * * *}$} \\
\hline White's test & \multicolumn{2}{|c|}{0.269} \\
\hline Breusch-Godfrey LM test & \multicolumn{2}{|c|}{0.261} \\
\hline Ramsey reset test & \multicolumn{2}{|c|}{0.483} \\
\hline
\end{tabular}

Note: ${ }^{* *}$ and ${ }^{* * *}$ indicate significance at the $5 \%$ and the $1 \%$ level, respectively. 
International Journal of Mathematical, Engineering and Management Sciences

Vol. 5, No. 6, 1270-1283, 2020

https://doi.org/10.33889/IJMEMS.2020.5.6.094
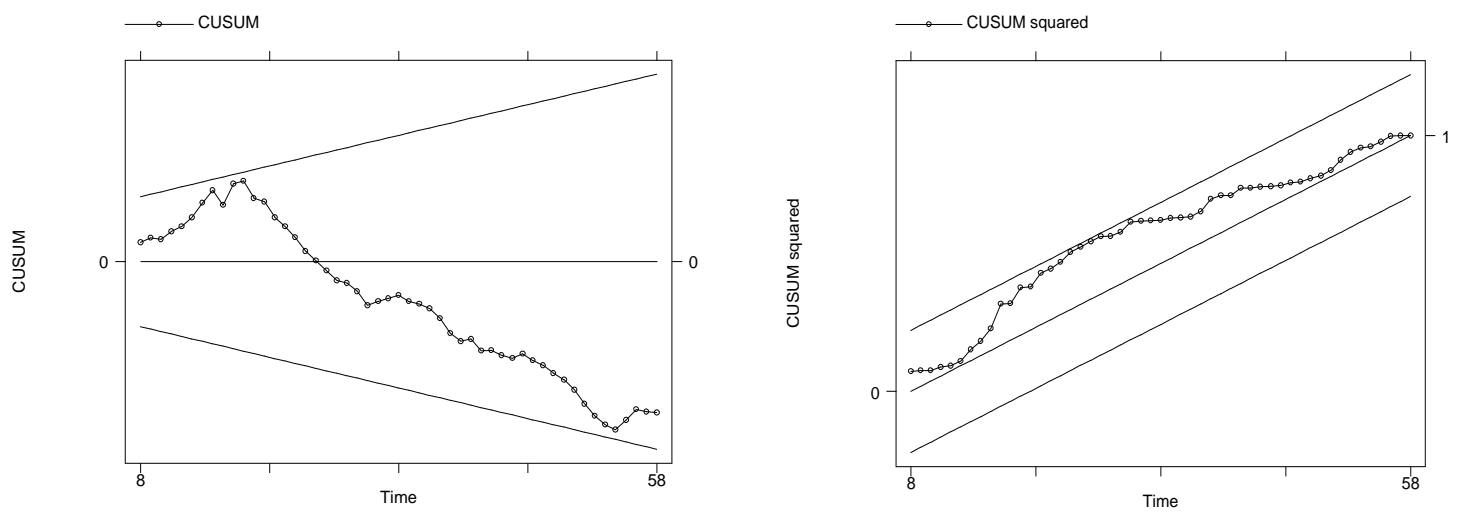

Figure 6. Stability tests (Model 1)

Table 4 shows that the results for autocorrelation, heteroscedasticity, and the Ramsey reset tests are valid. In addition, Model 1 is significant at the $1 \%$ level. Moreover, the CUSUM and CUSUM squared are within the standard bound at the 5\% significant level (Figure 6). Hence, Model 1 is stable and utilisable. The R-squared of Model 1 is $56.61 \%$, which means that the REM can account for $56.61 \%$ of the fluctuations in the stock market. This result reveals that the influence of the real estate market (REM) on stock market volatility $(\mathrm{SMV})$ is positive $(K=0.253)$ and significant at the $1 \%$ level in the short run. As control variables, in the short run and the long run, the impact of the consumer price index (CPI) on stock market volatility (SMV) is mainly concurrent.

Table 5. Coefficient estimation results (Model 2)

\begin{tabular}{|c|c|c|}
\hline \multirow{2}{*}{ VARIABLE } & \multicolumn{2}{|c|}{ MODEL 2} \\
\hline & Coef. & $\mathbf{P}>|\mathbf{t}|$ \\
\hline \multicolumn{3}{|l|}{ Long-run results } \\
\hline SMV & 1.019 & 0.129 \\
\hline GDP & 0.157 & 0.565 \\
\hline CPI & -0.020 & 0.780 \\
\hline GFC & $-0.024^{* * *}$ & 0.014 \\
\hline \multicolumn{3}{|l|}{ Short-run results } \\
\hline$\triangle \mathrm{SMV}$ & $0.421^{*}$ & 0.083 \\
\hline$\triangle \mathrm{GDP}$ & 0.065 & 0.583 \\
\hline$\triangle \mathrm{CPI}$ & -0.008 & 0.775 \\
\hline$\triangle \mathrm{GFC}$ & $-0.010^{* * *}$ & 0.016 \\
\hline $\operatorname{ECM}(-1)$ & $-0.413^{* * *}$ & 0.000 \\
\hline Constant & 0.007 & 0.400 \\
\hline R-squared & \multicolumn{2}{|c|}{$32.72 \%$} \\
\hline Significance level & \multicolumn{2}{|c|}{$0.000^{* * *}$} \\
\hline White's test & \multicolumn{2}{|c|}{0.677} \\
\hline Breusch-Godfrey LM test & \multicolumn{2}{|c|}{0.617} \\
\hline Ramsey reset test & \multicolumn{2}{|c|}{0.489} \\
\hline
\end{tabular}

Note: ${ }^{*},{ }^{* *}$, and ${ }^{* * *}$ indicate significance at the $10 \%, 5 \%$, and $1 \%$ level, respectively.

Table 5 reports the $1 \%$ significance level of Model 2. Its R-squared is $32.72 \%$, indicating that $32.72 \%$ of the fluctuations in the REM can be explained by those in the stock market. Table 5 and 
International Journal of Mathematical, Engineering and Management Sciences

Vol. 5, No. 6, 1270-1283, 2020

https://doi.org/10.33889/IJMEMS.2020.5.6.094

Figure 7 shows that the results of autocorrelation, heteroscedasticity, Ramsey reset tests, and Stability tests are appropriate, confirming its stability and validity. The results reveal that the REM is positively affected by stock market volatility in the short run $(K=0.421)$ at the $10 \%$ level of significance. In addition, the real estate market (REM) is negatively correlated to the global financial crisis (GFC) in the short run $(K=-0.010)$ and the long run $(\beta=-0.024)$ at the $5 \%$ level of significance.
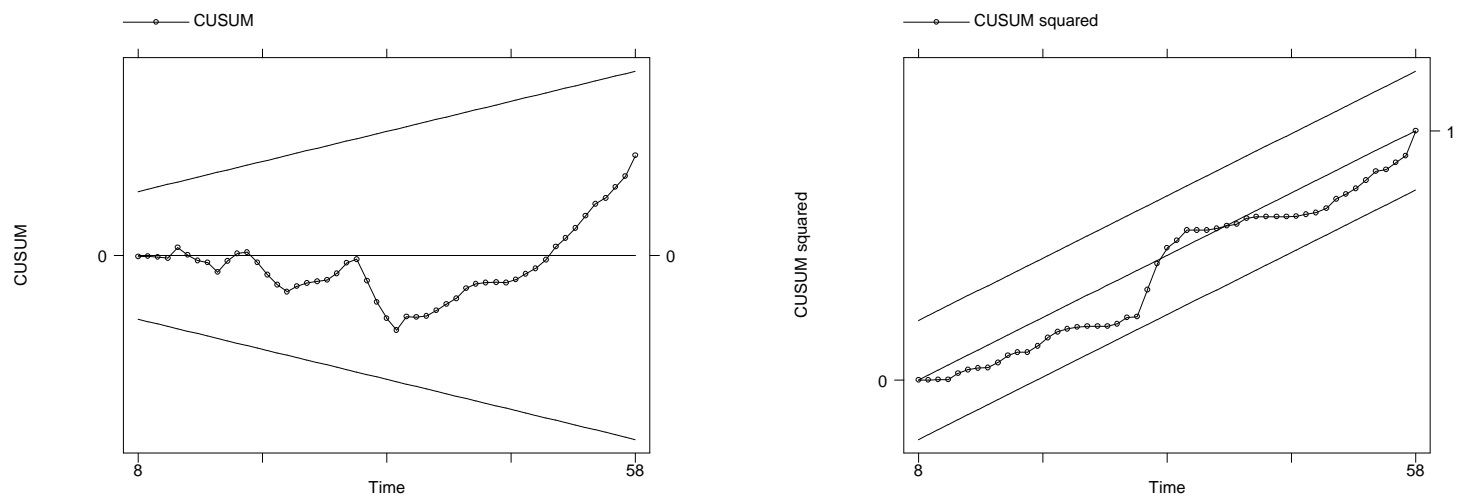

Figure 7. Stability tests (Model 2)

\subsection{Discussion}

The findings reveal the positive causality between the real estate market (REM) and stock market volatility (SMV) in Vietnam. To be specific, stock market volatility exerts a positive effect on the REM in the short run. In the reverse direction, the REM positively affects stock market volatility in the short run. Further, the paper confirms the negative association between the global financial crisis and the real estate market in the short run and the long run.

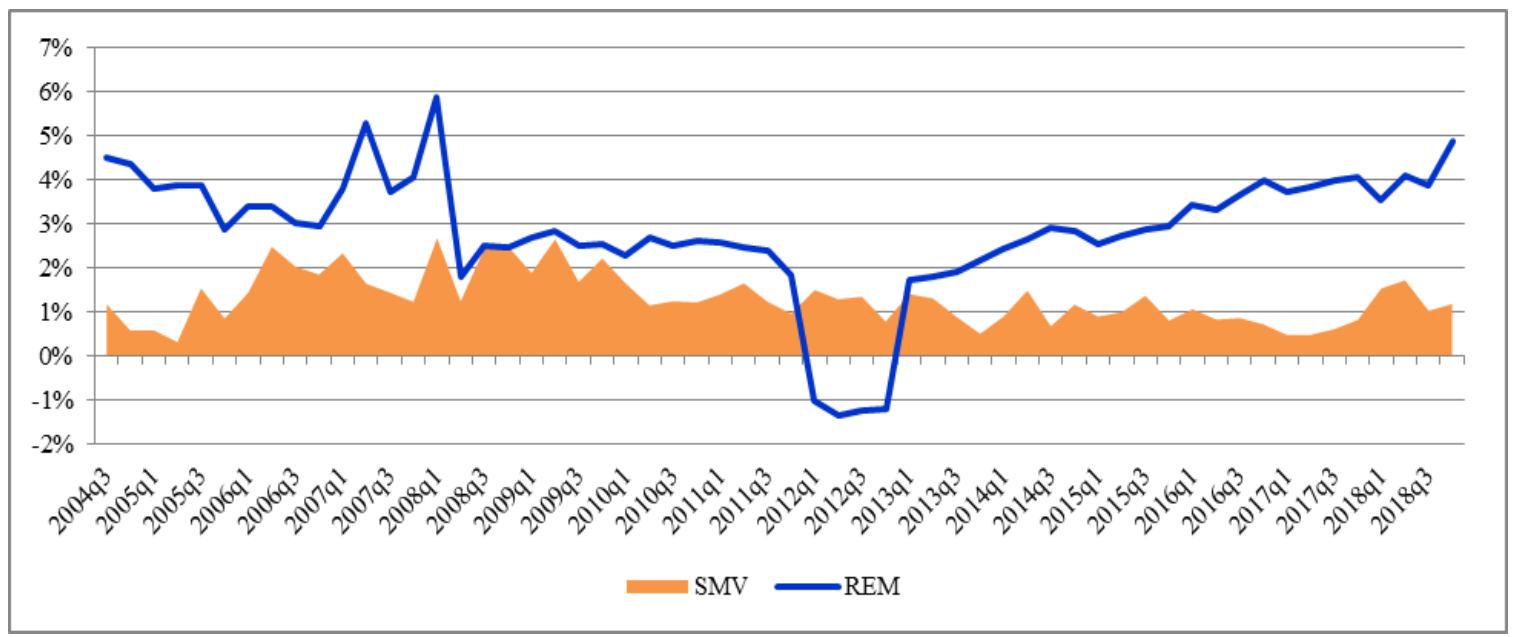

Figure 8. The real estate market and stock market volatility in Vietnam 
International Journal of Mathematical, Engineering and Management Sciences

Vol. 5, No. 6, 1270-1283, 2020

https://doi.org/10.33889/IJMEMS.2020.5.6.094

The Impact of the REM on Financial Stability: In the short run, the REM positively influences stock market volatility. This indicates that growth in the REM gives a rise to stock market volatility, or alternatively, a decline in financial stability. The positive correlation between the REM and stock market volatility is appropriate considering the credit effect and consistent with the findings of Heaney and Sriananthakumar (2012), Liu et al. (2020). It can be concluded that healthy growth in the real estate market gives a positive signal that boosts other sectors, including the stock market. Also, this growth allows more capital into the equity market, because it enables investors to easily access to capital via mortgage-based securities. This effect is obviously observed in Vietnam from the middle of 2007 to early 2008 (Figure 8), but only in the short run. This is because Vietnam's real estate and stock markets are quite young and unstable, so shortrun declines are insufficient to create a long-run effect, as occurs in developed countries.

The Impact of Financial Stability on the REM: In the short run, stock market volatility has a positive effect on the REM. This corroborates the wealth effect and what has been reported by Heaney and Sriananthakumar (2012), Liu et al. (2020). Accordingly, more fluctuations in the stock market (low financial stability) cause the development in the real estate market. This is because dramatic growth in the stock market stimulates capital to REM, thereby boosting it. However, an excessive and uncontrolled rise in property capital leads to many potential risks in the real estate market, possibly producing bubbles and crises, of which the global financial crisis in 2007 is a typical example. In Vietnam, this impact is clearly shown during the global financial crisis (Figure 8). Moreover, a considerable decline in the stock market may lead investors to make more investments in the REM, thereby boosting it.

\section{The impact of the Global Financial Crisis on the REM:}

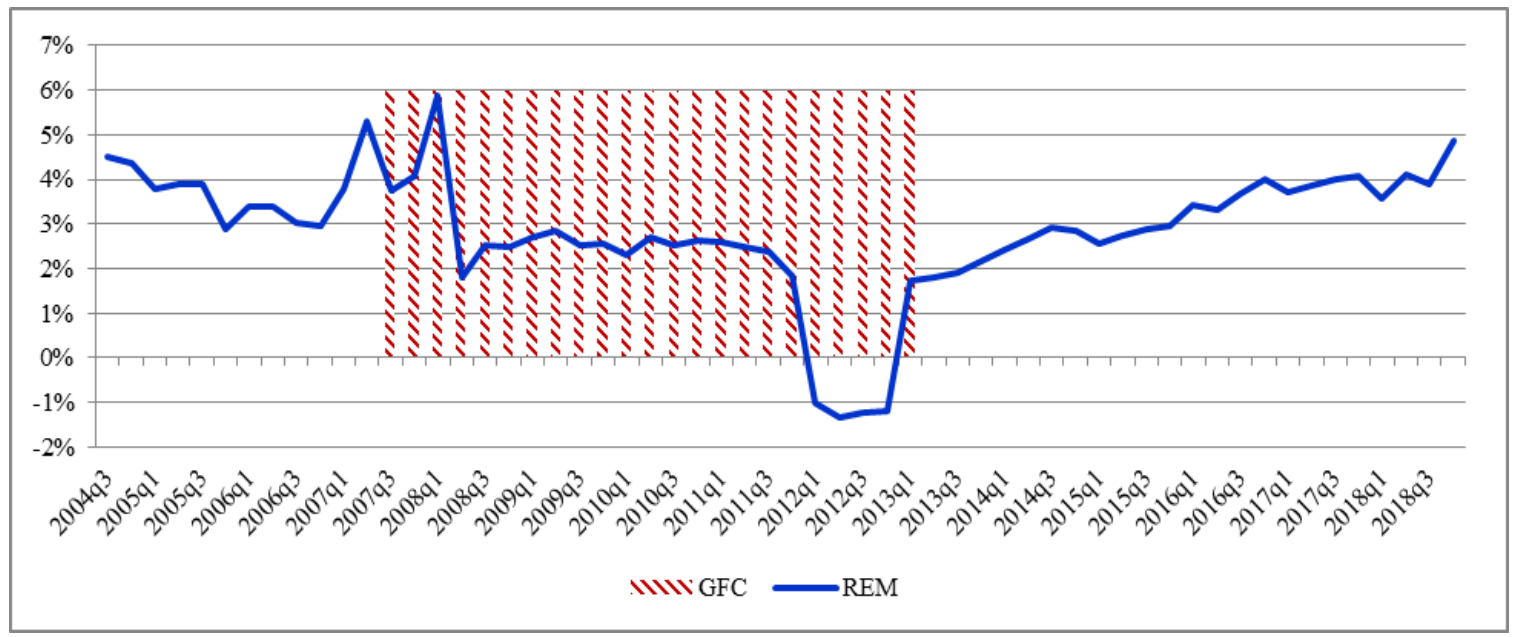

Figure 9. The global financial crisis and the REM in Vietnam

It can be seen that the global financial crisis negatively influences the REM in the short run and the long run. This is a novelty of this study. Indeed, together with the remarkable achievements in global integration, the global financial crisis had an unavoidable impact on Vietnam's real estate market. During the crisis, the world economy, including Vietnam, experienced many predicaments, including a decrease in trading and difficulties in capital access, which produced a 
International Journal of Mathematical, Engineering and Management Sciences

Vol. 5, No. 6, 1270-1283, 2020

https://doi.org/10.33889/IJMEMS.2020.5.6.094

dramatic decline in the real estate market. Specifically, during the global financial crisis, Vietnam real estate industry decreased dramatically, even sometimes grew by $-1.34 \%$ as compared to the same period last year (Figure 9).

\section{Conclusion}

With the objective of analysing the correlation between the real estate market and financial stability in Vietnam, we employ the ARDL approach, which generates more valid results than its counterparts. Financial stability is measured using stock market volatility. In particular, high stock market volatility corresponds to low financial stability and vice versa. The paper provides the first empirical evidence on the positive association between the real estate market and stock market volatility in Vietnam. However, this relationship only exists in the short run, which is a distinctive feature of Vietnam as compared to developed countries. Furthermore, the paper reveals an unprecedented finding that is the negative impact of the global financial crisis on the REM in the short run and the long run.

These findings are the first empirical evidence on the link between the real estate market and financial stability in Vietnam, a developing economy. Therefore, they are essential not only to Vietnam but also to other developing countries. They also provide policy makers with a comprehensive perspective on this correlation in developing countries. In specific, they can design suitable policies for a healthy financial system together with the sustainable real estate market. Despite achieving its objectives, the study still has its limitation when only considering financial stability from the angle of the stock market but not the banking sector or the entire financial system. Investigating these perspectives may be an interesting proposal for future research.

\section{Conflict of Interest}

The authors confirm that there is no conflict of interest to declare for this publication.

\section{Acknowledgements}

The authors would like to express their sincere thanks to the editor and anonymous reviews for their time and valuable suggestions.

\section{References}

Bahmani-Oskooee, M., \& Ghodsi, S.H. (2018). Asymmetric causality between the U.S. housing market and its stock market: Evidence from state level data. The Journal of Economic Asymmetries, 18, 1-8.

Bui, T.N. (2019a). Inflation and stock index: evidence from Vietnam. Journal of Management Information and Decision Science, 22(4), 408-414.

Bui, T.N. (2019b). The role of financial development in the Vietnam economy. WSEAS Transactions on Business and Economics, 16, 471-476.

Bui, T.N. (2020). Stock holding decisions of foreign investors in emerging stock markets: A case study in Vietnam. Management Science Letters, 10(3), 625-630.

Cayon, E., Thorp, S., \& Wu, E. (2018). Immunity and infection: Emerging and developed market sovereign spreads over the Global Financial Crisis. Emerging Markets Review, 34, 162-174. 
International Journal of Mathematical, Engineering and Management Sciences

Vol. 5, No. 6, 1270-1283, 2020

https://doi.org/10.33889/IJMEMS.2020.5.6.094

Choi, C., \& Park, K. (2017). Financial system and housing price. Emerging Markets Finance and Trade, 54(2), 328-335.

Dickey, D.A., \& Fuller, W.A. (1979). Distribution of the estimators for autoregressive time series with unit root. Journal of the American Statistical Association, 74(366a), 427-431.

Ding, H., Chong, T.T.L., \& Park, S.Y. (2014). Nonlinear dependence between stock and real estate markets in China. Economics Letters, 124(3), 526-529.

Heaney, R., \& Sriananthakumar, S. (2012). Time-varying correlation between stock market returns and real estate returns. Journal of Empirical Finance, 19(4), 583-594.

Huang, D.J., Leung, C.K., \& Qu, B. (2015). Do bank loans and local amenities explain chinese urban house prices? China Economic Review, 34, 19-38.

Hui, E.C., \& Chan, K.K.K. (2014). The global financial crisis: Is there any contagion between real estate and equity markets? Physica A: Statistical Mechanics and its Applications, 405, 216-225.

Ibrahim, M.H. (2010). House price-stock price relations in Thailand: an empirical analysis. International Journal of Housing Markets and Analysis, 3(1), 69-82.

Illing, M., \& Liu, Y. (2006). Measuring financial stress in a developed country: An application to Canada. Journal of Financial Stability, 2(3), 243-265.

Kapopoulos, P., \& Siokis, F. (2005). Stock and real estate price in Greece: wealth versus 'credit-price' effect. Applied Economics Letters, 12(2), 125-128.

Kiyotaki, N., \& Moore, J. (1997). Credit cycles. Journal of Political Economy, 105(2), 211-248.

Lambertini, L., Mendicino, C., \& Punzi, M.T (2017). Expectations-driven cycles in the housing market. Economic Modelling, 60, 297-312.

Lean, H.H., \& Smyth, R. (2014). Dynamic interaction between house prices and stock prices in Malaysia. International Journal of Strategic Property Management, 18(2), 163-177.

Lin, P.T., \& Fuerst, F. (2014). The integration of direct real estate and stock markets in Asia. Applied Economics, 46(12), 1323-1334.

Lin, T.C., \& Lin, Z.H. (2011). Are stock and real estate markets integrated? An empirical study of six Asian economies. Pacific-Basin Finance Journal, 19(5), 571-585.

Liu, C., Zheng, Y., Zhao, Q., \& Wang, C. (2020). Financial stability and real estate price fluctuation in China. Physica A: Statistical Mechanics and its Applications, 540, 122980.

Liu, Y.S., \& Su, C.W. (2010). The relationship between the real estate and stock markets of China: Evidence from a nonlinear model. Applied Financial Economics, 20(22), 1741-1749.

Markowitz, H. (1952). Portfolio selection. Journal of Finance, 7(1), 77-91.

Moscone, F., Tosetti, E., \& Canepa, A. (2014). Real estate market and financial stability in US metropolitan areas: A dynamic model with spatial effects. Regional Science and Urban Economics, 49, 129-146.

Nguyen, M.L.T., \& Bui, T.N. (2019). Stock market, real estate market, and economic growth: an ARDL approach. Investment Management and Financial Innovations, 16(4), 290-302.

Nguyen, M.L.T., Bui, T.N., \& Nguyen, T.Q. (2019). Relationships between Real Estate Markets and Economic Growth in Vietnam. Journal of Asian Finance, Economics and Business, 6(1), 121-128.

Nguyen, M.L.T., Pham, T.T.X, \& Bui, T.N. (2020). Causal relationship between banking system development and real estate market. Management Science Letters, 10(1), 41-52.

Pahlavani, M., Wilson, E., \& Worthington, A.C. (2005). Trade-GDP nexus in Iran: An application of the autoregressive distributed lag (ARDL) model. American Journal of Applied Sciences, 2(7), 1158-1165. 
International Journal of Mathematical, Engineering and Management Sciences

Vol. 5, No. 6, 1270-1283, 2020

https://doi.org/10.33889/IJMEMS.2020.5.6.094

Park, C.Y., \& Mercado Jr, R.V. (2014). Determinants of financial stress in emerging market economies. Journal of Banking \& Finance, 45(C), 199-224.

Pesaran, M.H., Shin, Y., \& Smith, R.J. (2001). Bounds testing approaches to the analysis of level relationship. Journal of Applied Econometrics, 16(3), 289-326.

Petrova, T. (2010). What are the effects of housing prices and the REIT index in Bulgaria on the Bulgarian stock exchange index? Park Place Economist, 18(1), 41-47.

Pradhan, R.P., Arvin, M.B., Hall, J.H., \& Bahmani, S. (2014). Causal nexus between economic growth, banking sector development, stock market development, and other macroeconomic variables: The case of ASEAN countries. Review of Financial Economics, 23(4), 155-173.

Quigley, J.M. (2001). Real estate and the Asian crisis. Journal of Housing Economics, 10(2), 129-161.

Raza, N., Ali, S., Shahzad, S.J.H., \& Raza, S.A. (2018). Do commodities effectively hedge real estate risk? A multi-scale asymmetric DCC approach. Resources Policy, 57, 10-29.

Shi, G., Liu, X., \& Zhang, X. (2017). Time-varying causality between stock and housing markets in China. Finance Research Letters, 22, 227-232.

Tsai, I.C., Lee, C.F., \& Chiang, M.C. (2011). The asymmetric wealth effect in the US housing and stock markets: evidence from the threshold cointegration model. Journal of Real Estate Finance and Economics, 45, 1005-1020.

Tursoy, T., \& Faisal, F. (2016). Causality between stock price and GDP in Turkey: an ARDL bounds testing approach. Romanian Statistical Review, 64(4), 3-19.

Zhang, H., Li, L., Hui, E.C.M., \& Li, V. (2016). Comparisons of the relations between housing prices and the macroeconomy in China's first-, second- and third-tier cities. Habitat International, 57, $24-42$. 